Osoba i doświadczenie mistyczne (2) „Filozofia Chrześcijańska” 14 (2017), s. 53-70 doi: $10.14746 /$ fc. 2017.14 .3

\author{
KRZYSZTOF BIELAWSKI \\ Uniwersytet Jagielloński w Krakowie \\ Instytut Filologii Klasycznej
}

\title{
Doświadczenie mistyczne w mitraizmie ${ }^{1}$
}

Na jakiej podstawie i czy w ogóle można mówić o doświadczeniu mistycznym, wyłączywszy swoje własne? Starożytność grecka znalazła na to pytanie odpowiedź: arrheton - „niewypowiadalne”2.

Jednak - już to z tęsknoty, już to z zazdrości, już to z nadziei na poznanie i zrozumienie tego, czego nam brak, a czego intuicję mamy - nieustannie usiłujemy to doświadczenie u innych badać i opisywać. Na jakiej podstawie? Wydaje się, że wyłącznie na podstawie źródeł, tekstów, które nazywamy świadectwami, napisanych przez tych, którzy takie doświadczenie mieli albo też usiłowali - jak my - je sobie wyobrazić. Może też na podstawie opinii, komentarzy i opisów tych, którzy doświadczenia tego dotykali jakby pośrednio, obcując z czymś, co przekraczało ich zdolności i możliwości, ale co było na tyle zdumiewające i silne, że w transformujący sposób przeniknęło do ich myśli i uczuć? Mistycy mają swoich biografów. O mistyce Benedykta z Nursji pisał Grzegorz Wielki w Dialogach, o doświadczeniu św. Pawła z Tarsu - św. Łukasz (owszem, sam Paweł też). Sam język mistyki znalazł dwie drogi wyrazu: poezję i filozofię. Obie łączą się w metaforze i alegorii, które zrodziły się z fundamentalnego przekonania o niewyrażalności (arrheton) takiego doświadczenia. Niewyrażalność jest istotą mistyki - tak było od starożytności. Arrheton jest dla mistyki starożytnej, tak samo jak dla wczesnochrześci-

${ }^{1}$ Badania nad podjętym tutaj tematem i opracowanie niniejszego artykułu były możliwe dzięki środkom Narodowego Centrum Nauki przyznanym na podstawie decyzji numer DEC-2013/09/B/ /HS2/01208.

${ }^{2} \mathrm{Na}$ ten temat zob. K. Bielawski, Arrheton - niewypowiadalne $w$ greckich kultach misteryjnych, „Filozofia Chrześcijańska” 13 (2016), s. 37-52. 
jańskiej pojęciem podstawowym ${ }^{3}$. De facto więc zawsze i tak wnioskujemy z pozorów, z odbicia w lustrze języka, tego, co w swym ostatecznym wyrazie i najgłębszym sensie pozostaje niewypowiadalne. W teologii chrześcijańskiej to poezja stała się jedynym skutecznym środkiem komunikacji doświadczenia mistycznego ze światem słów. Tradycja Kościoła wschodniego miano „teologa" przypisała tylko trzem osobom: Janowi Ewangeliście, Grzegorzowi z Nazjanzu i Symeonowi Nowemu Teologowi - wszyscy uchodzą za mistyków, ale łączy ich przede wszystkim to, że byli poetami ${ }^{4} \mathrm{i}$ ich teologiczna przenikliwość szła w parze z poetycką wrażliwością. O doświadczeniu wnioskujemy z metafory, która - jak inne dzieła sztuki - tyle samo odsłania, ile zakrywa.

Zdarza się jednak, że metaforycznego, poetyckiego lub filozoficznego opisu doświadczenia mistycznego po prostu nie ma, ale naszym oczom odsłania się kontekst, wyłaniający się z podań, odbić krzywego zwierciadła dalekich komentarzy, podań, archeologii i sztuki, nie tyle opowiadając o mistycznym doświadczeniu, ile na nie wskazując.

Wolno chyba zadać pytanie, czy istnieje aż taka wielka różnica między wnioskowaniem z metafory, która próbuje przebić się przez arrheton do wypowiadalności, a wnioskowaniem z kontekstu tego doświadczenia, nawet jeśli nie mamy jego bezpośredniego zapisu? Tam, gdzie brakuje tekstów bezpośrednio odnoszących się do doświadczenia osobistego, pozostaje wnioskować z danych pośrednich, idąc za tą samą intuicją i tęsknotą, na które odpowiadamy lekturą pism mistyków.

Intuicyjnie rozpoznajemy doświadczenie mistyczne wszędzie tam, gdzie niewyrażalność, tajemnica i boskość stają na pierwszym planie. Zwykliśmy dość arogancko wyrokować o prawdzie lub fałszu cudzych doświadczeń na podstawie własnych przekonań i intuicji. Nawet Kościół instytucjonalny z wielką ostrożnością, by nie rzec nieufnością, odnosi się do takich doświadczeń we własnym łonie, często wyrokując o ich nieprawdziwości lub poddając je trudnej próbie czasu i ortodoksji. Jednak świadomość tajemnicy pociąga i pobudza, ponieważ właśnie to, co zakryte i niewyrażalne, jest tym, do czego najbardziej tęsknimy.

Dla religioznawcy literatura jest dość niepewnym źródłem: jest świadectwem ludzkich wyobrażeń, często ludzkiego geniuszu i wyjątkowej wrażliwości, ale nigdy nie wiemy, jak dalece jest fikcyjna. Herodot nie jest historykiem w dzisiejszym znaczeniu tego słowa, ale raczej etnografem i reporterem, znaczącym swoje zapisy głęboką i nieskrywaną bynajmniej subiektywnością.

${ }^{3}$ Przywołany powyżej artykuł na temat arrheton nie zawiera analizy wystąpień tego terminu w literaturze wczesnochrześcijańskiej, która dostarcza niezwykle bogatego materiału i nadal czeka na opracowanie.

${ }^{4} \mathrm{Na}$ ten temat zob. M. Bielawski, Tytut teologa. Casus Jana Ewangelisty, Grzegorza z Nazjanzu i Symeona Nowego Teologa, w: tenże, Mikroteologie, Kraków 2008, s. 11-28. 
Dionizos literatury i Dionizos kultu to dwie różne postaci. Dionizos Bakchantek Eurypidesa i Dionizos inskrypcji kultowych lub archeologii to dwa różne bóstwa. Mitologia Parandowskiego jest miłą lekturą dla dzieci, ale nie daje najmniejszego pojęcia o złożoności mitu i jego relacji z rzeczywistym kultem, o którym więcej wiemy z epigrafiki i archeologii.

Czynię ten wstęp, ponieważ mamy zając się tutaj religią, która nie pozostawiła nam żadnego bezpośredniego i pewnego zapisu „od wewnątrz”, ,„z pierwszej ręki”. Religią, której istotą było mysterion, a kategoria arrheton w obydwu sensach: 'niewypowiadalne' i 'takie, którego pod żadnym warunkiem nie wolno wypowiedzieć', była stosowana z taką konsekwencją, że nikt nie ośmielił się i nikt nie potrafił jej przekroczyć. Pozostały dane archeologiczne - bardzo bogate - i okruchy świadectw pisanych, zawsze tylko „z zewnątrz”, „z drugiej ręki”. Sądzę jednak, że z tych pośrednich danych i z tych okruchów niejedno można wnioskować - jak z poezji Jana, Grzegorza i Symeona lub też ruin i pozostałości wczesnochrześcijańskich baptysteriów.

\section{Mitraizm}

W Rzymie, około roku 400 n.e., grupa chrześcijan uzbrojonych w siekiery sforsowała sobie drogę do świątyni mitraistycznej na Awentynie, żeby zniszczyć posągi, rzeźby i freski, a pomieszczenie wypełnić śmieciami ${ }^{5}$. Niedawno prześladowani, sami stali się prześladowcami, a rosnąca nieustannie liczba wyznawców Mitry była przez nich postrzegana jako śmiertelne zagrożenie ${ }^{6}-$ abstrahując już od konsekwencji samego edyktu Teodozjusza. Na miejscu tej świątyni Mitry, a dokładniej: na niej, czy też nad nią, na Awentynie stanęła chrześcijańska świątynia - i stoi tam do dzisiaj - kościół Santa Prisca. Mitreum, miejsce kultu boga Mitry, odkopano w roku 1935 podczas renowacji kościoła. Samo mitreum powstało w II wieku n.e. w piwnicach domu z czasów Hadria$\mathrm{na}^{7}$. Do tych zniszczonych siekierami fresków jeszcze przyjdzie nam powrócić.

Słynne zdanie Ernesta Rénana, pierwszego poważnego badacza tego zjawiska: „Gdyby wzrost chrześcijaństwa zatrzymała jakaś śmiertelna choroba, w świecie zapanowałby Mitra"», w którym zawarł myśl, że gdyby nie Konstantyn, świat byłby mistraistyczny, a nie chrześcijański, jest z pewnością retoryczną przesadą - świat bez chrześcijaństwa nie byłby mistraistyczny, tylko wieloreligijny, jak cała rzeczywistość religijna późnego antyku, w którym

${ }^{5}$ Być może do tego wydarzenia nawiązuje św. Hieronim w przywołanym poniżej Liście 107.

${ }^{6}$ M.J. Vermaseren, Mithras. The Secret God, London 1963, s. 11.

7 Tenże, Corpus Inscriptionum et Monumentorum Religionis Mithraicae, t. 1, Hagae 1956, s. 193.

${ }^{8}$ E. Rénan, Marc Aurèle et la fin du monde antique, Paris 1882, s. 579. 
chrześcijaństwo, nierzadko siekierami, wyrąbało sobie drogę do hegemonii. Jest w nim też jednak zawarta historyczna prawda o niezwykłej sile i powszechności mitraizmu.

Mit tajemniczego boga Mitry i jego wyznawców, tajemnych zgromadzeń, wspólnot i inicjacji pozostał żywy i nieustannie powracał w krótkich wzmiankach do samego końca starożytności, a potem w słownikach leksykografów bizantyjskich ${ }^{9}$. Prawdziwy renesans mitraizm przeżył i przeżywa nadal od czasów prac belgijskiego badacza Franza Cumonta (1868-1947) z początków XX wieku, ojca nowożytnych badań nad tym zjawiskiem. Badano związki mitraizmu z chrześcijaństwem i zastanawiano się, jak przebiegało to starcie między dwoma wielkimi ruchami religijnymi. Zwracano uwagę na podobieństwa i wzajemne wpływy: na to, że nazwa sacramentum, pierwotnie oznaczająca przysięgę wojskową, trafić musiała do języka teologii chrześcijańskiej bezpośrednio z mitraizmu - religii legionów rzymskich, że w obu kultach sprawowano rytualne uczty i jakieś podobne formy chrztu; że w obydwu obowiązywała tajemnica, tyle że w mitraizmie - absolutna i niepoddająca się zmiękczającej ewolucji związanej z coraz większym przenikaniem do życia publicznego i politycznego; że od rekrutów obydwu wymagano nie tylko gotowości przyjęcia wiary i sprawowania kultu, ale też istotnej zmiany życia, że wyznawcy tworzyli wspólnoty, przeżywające razem nie tylko liturgie, ale też pomagające sobie wzajemnie w codziennym życiu. Badano rozległość rozprzestrzeniania się - setki mitreów z III wieku spokojnie konkurują liczebnie za świątyniami i miejscami kultu chrześcijan - od Afryki i Azji Mniejszej po Szkocję, Germanię i Hiszpanię.

$\mathrm{O}$ istotnych różnicach między obydwoma kultami dużo trudniej mówić mimo 200 niemal lat nieustannych badań, ponieważ materiału mitraistycznego jest przerażająco mało. $Z$ pewnością mitraizm łatwiej funkcjonował w politeistycznym świecie hellenistycznej i cesarskiej kultury, wyraziście się odznaczał od innych form kultu, ale - jak wszystkie inne kulty pogańskie nie wymagał wyłączności. W inskrypcjach mitraistycznych pojawia się Zeus, Helios, Hermes, Posejdon, Okeanos. Z pewnością kult opierał się na silnym doświadczeniu osobistym, które było objęte, traktowaną niesłychanie poważnie, tajemnicą. Trudno wyrokować o istnieniu i funkcjonowaniu kapłaństwa nie wiadomo, czy najwyższy stopień wtajemniczenia był równoznaczny z tym urzędem, czy nie i jak należałoby rozumieć kapłaństwo w tym kontekście. Mitraiści składali ofiary. Składali też chleb i wodę w kielichach.

Walter Burkert uważał, że „mitraizm nie był nawet w pełnym znaczeniu tego słowa religią" "10, z czym trudno się zgodzić, nawet jeśli jest to sąd wynikający z ubóstwa źródeł. Wszystko w nim koncentrowało się wokół obrzę-

\footnotetext{
9 Por. np. leksykon Suda, s.v. Mí日pov.

10 Starożytne kulty misteryjne, thum. K. Bielawski, Bydgoszcz 2001, s. 40.
} 
dów inicjacyjnych sprawowanych przez sekretne wspólnoty. Brak świadectw pisanych rekompensują dość obfite dane archeologiczne. Można domniemywać, że dzisiaj dostępność mitreów w muzeach i miejscach archeologicznych wykopalisk jest nieporównywalnie większa niż kiedykolwiek w czasach, gdy funkcjonowały jako świątynie. Tajemnica. Zamknięcie. Niewielkie wspólnoty - najwyżej do 20 osób. Hierarchiczna struktura. Intensywność doświadczenia, przenoszona na życie codzienne poza świątynią. Wszystko to daje obraz kultu o wyjątkowej intensywności, ale też religii totalnej i zorganizowanej, misyjnej, obraz doświadczenia całkowitego, które obejmuje wszystkie dziedziny życia.

Pod wpływem badań Franza Cumonta mitraizm stał się popularny nie tylko w religioznawstwie. Oddziaływał na nurty ezoteryczne i kulturę. Już w 1926 roku powstał nawet dramat opisujący losy wtajemniczanych mystów: Kenneth Sylvan Guthrie, The Mithraic Mysteries Resored and Modernized. A Drama of Interior Initiation. Employing all the available Data and Survivals of the Historic Persio-Roman Mithraics, Embodying Versions of Zoroastrian Scriptures. Combining the Religions of All Races and Times, With the best Modern Spiritual Thought, With Experiments for Every Day of the Year, Teocalli, 1925. Każda „scena” tego dramatu kończy się spisem zadań, jakie należy wykonać w duchowym postępie, jak ćwiczenia duchowe czy poradnik doskonalenia wewnętrznego. Kosmiczny i astrologiczny charakter niektórych świadectw archeologicznych kieruje ku mitraizmowi uwagę współczesnych nurtów ezoterycznych, związanych z kulturą New Age.

\section{Kim był Mitra i czym był mitraizm?}

Mitra jest bardzo starym, indoirańskim bóstwem, znanym już od epoki brązu i czczonym wszędzie tam, gdzie dotarła kiedykolwiek dominacja perska. Imię Mitry oznacza 'tego, który jest pomiędzy', coś jak 'przymierze', 'pakt', 'traktat' czy 'obietnica lojalności'11. W irańskiej Aweście Mitra określany był jako „Pan Zobowiązań”, duch wszelkich umów, personifikacja lojalności, panował nad kosmicznym ładem, zmianami pór roku i dnia, pełnił też obowiązki sędziego podczas sądu nad duszami zmarłych. Pojawia się też w podobnych funkcjach w indyjskich Rigwedach ${ }^{12}$.

Brak jest jakichkolwiek szczegółowych danych na temat mitraizmu w jego rzymskiej odsłonie sprzed roku 100 p.n.e., kiedy dociera on do Rzymu wraz z legionami i kupcami, spośród których rekrutowali się w większości

11 W. Burkert, Starożytne kulty..., dz. cyt., s. 44.

12 Zob. A.D.H. Bivar, The Personalities of Mithra in Archaeology and Literature, New York 1998, zwłaszcza rozdziały „The Personalities of Mithra” i „The Five Emanations of Mithra”. 


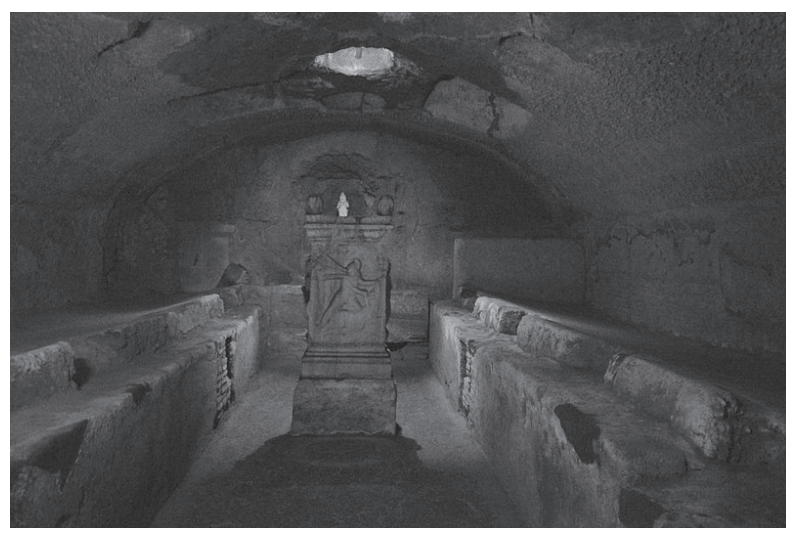

Mitreum pod kościołem San Clemente w Rzymie (licencja otwartego dostępu za Wikimedia Commons)

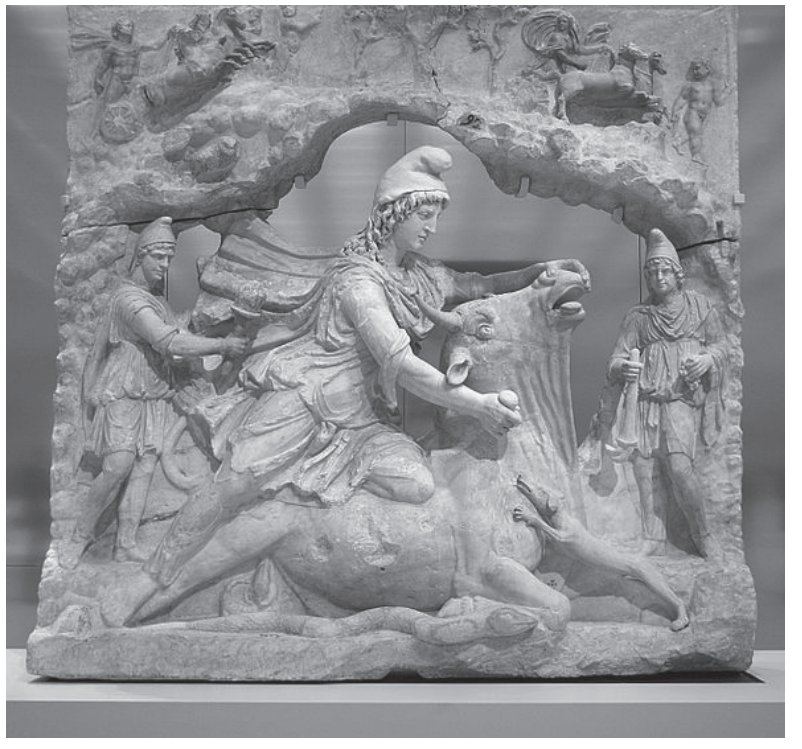

Relief marmurowy z mitreum z Kapitolu w Rzymie, II w. n.e., fot. J.P. Grandmont (licencja otwartego dostępu za Wikimedia Commons)

jego wyznawcy. Z ikonografii i epigrafiki wiemy jedynie, że istniał i ekspandował. Nadal nie wiemy nic na temat genezy tego kultu w jego rzymskiej odsłonie, jego ciągłości i związków z szerszym kontekstem dawnych religii perskich $^{13}$.

Kult Mitry sprawowano w jaskiniach, jak pisze Porfiriusz: ,[...] gdziekolwiek uznają Mitrę, oddają temu bogu cześć w jaskini” (Grota nimf, 2014) -

13 Pełna bibliografia na ten temat zob. W. Burkert, Starożytne kulty..., dz. cyt., s. 45, przyp. 29.

14 Tłumaczenie P. Ashwin-Siejkowski, według wydania: Porfiriusz z Tyru, Grota nimf, thum. wstęp i opracowanie P. Ashwin-Siejkowski, Kraków 2006, s. 61. 
Mitra był „bogiem ze skały” (ek petras theos). Później natomiast w budowlach stylizowanych na jaskinie, gdzie niewielkie wspólnoty wiernych spotykały się, aby sprawować liturgię, obrzędy inicjacyjne i rytualne posiłki przed podobizną Mitry zabijającego byka. Podobizna ta - najczęściej w postaci rzeźby lub płaskorzeźby - znajdowała się zawsze centralnie u szczytu pomieszczenia, w jego swoistej apsydzie.

Mistraistyczna ikonografia jest zdumiewająco jednolita, konsekwentna i bardzo symboliczna, odpowiada zapewne z jednej strony spójnej opowieści mitycznej, a z drugiej radykalnie przestrzeganym zasadom inicjacji, które nie ulegały przekształceniom.

\section{Mit}

Mit Mitry - jak pisze niemal sarkastycznie Burkert - „Z pewnością istniał" 15 . Dziś odtwarzamy go niemal wyłącznie z przedstawień ikonograficznych, wśród których dominuje przedstawienie boga zabijającego byka. W zapisach słownych zachował się w związku z tym tylko zagadkowy wyraz bouklopos [theos] - 'złodziej bydła' (u Porfiriusza, Grota nimf, 18 ${ }^{16}$ ). W cyklu przedstawień można rozpoznać sceny teogoniczne z Okeanosem, Kronosa oddającego dobrowolnie berło Zeusowi, Zeusa walczącego z gigantami oraz narodziny Mitry ze skały. Nie wiadomo, kto był ojcem Mitry. Istnieją sceny z Mitrą, który poszukuje byka, ściga go (może kradnie?), ujarzmia i dosiada, by w końcu zawlec go do groty i złożyć w ofierze. Widzimy też Mitrę wsiadającego do rydwanu Heliosa. Jest też tajemnicze malowidło, na którym Helios kłania się przed Mitrą, wymachującym jakimś przedmiotem.

Mitra rzekomo urodził się ze skały (de petra natus), co uzasadnia znaczenie grot i jaskiń w kulcie mitraistycznym, czemu kilka zdań poświęcił w swym dziele o grotach Porfiriusz (zob. powyżej). Mitra jest równy Słońcu - Heliosowi, istnieją przedstawienia obydwu bogów ściskających sobie dłonie, przekazujących sobie jakieś przedmioty lub biesiadujących przy wspólnej uczcie z ofiarnego byka. On sam nazywany był na wotywnych stelach Sol Invictus, a czczono go 25 grudnia.

Mamy tu stałe motywy mitologiczne, pojawiające się także w innych opowieściach kultury śródziemnomorskiej: teogonię, motyw poszukiwania, ustanowienie ofiary, oswajanie byka (Herakles), kradzież bydła (Hermes). Toposy poszukiwania i walki mają dobrze poświadczone wzorce czy analogie od teo-

15 W. Burkert, Starożytne kulty..., dz. cyt., s. 138.

16 Tamże; Burkert jednoznacznie łączy ten przydomek z Mitrą, chociaż kontekst nie jest oczywisty, w moim przekonaniu może chodzić równie dobrze o Hermesa. 


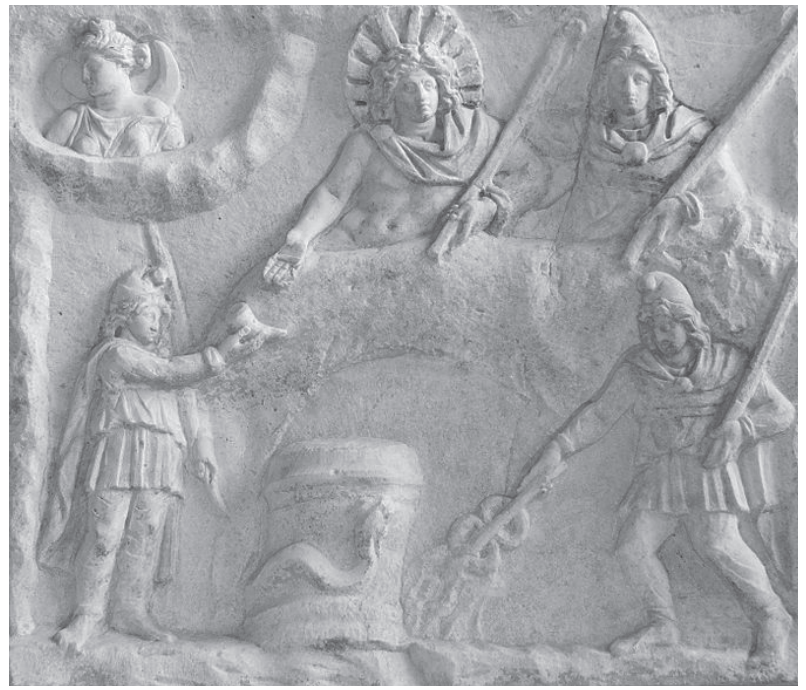

Mitra i Helios, relief z III w. n.e. z Fiano Romano koło Rzymu, obecnie w muzeum w Denon. Fot. Marie-Lan Nguyen (licencja z domeny publicznej za Wikimedia Commons)

gonii babilońskich po Hezjoda ${ }^{17}$. Rekonstrukcja mitu Mitry na obecnym etapie znajomości źródeł jest jednak niemożliwa.

\section{Kult}

Wszystkie źródła określają kult Mitry jako misteryjny. Terminologia jest jednoznaczna: mowa jest zawsze albo o mysteria ( $\mu \nu \sigma \tau \hat{p} \rho \iota \alpha$ ), albo o teletai

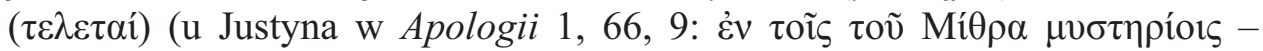
„w misteriach mitry”; u Porfiriusza w De abstnentia 2, 56, gdzie przywołuje on dzieło niejakiego Pallasa pod tytułem $O$ misteriach Mitry: $\varphi \eta \sigma i ̀ ~ П \alpha ́ \lambda \lambda \lambda \alpha \varsigma$

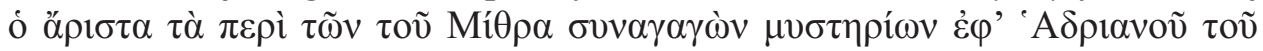

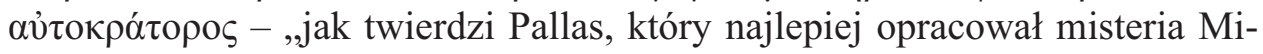
try w czasach Hadriana", podobnie w Grocie nimf 15; u Orygenesa w Contra

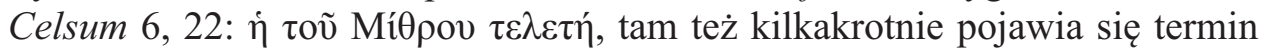

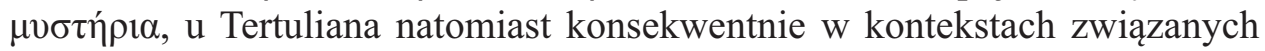
z mitraizmem mamy pojęcia initiare czy initiatio, np. Cor., 15).

Jako szczególna cecha mitraizmu na tle innych starożytnych kultów misteryjnych rzuca się w oczy jego radykalnie wspólnotowy charakter - całość kultu jest ograniczona do ścisłej wspólnoty wiernych i jednego miejsca spra-

17 W. Burkert, Starożytne kulty..., dz. cyt., s. 138-139. 
wowania obrzędów. Jest to też jedyny starożytny kult pogański, w którym nie dopuszczano ofiar prywatnych ${ }^{18}$.

Wydaje się, że mitraizm był również religią par excellence wotywną ogromna większość zachowanych inskrypcji z mitreów to napisy o charakterze wotywnym; ofiary (= datki i inskrypcje) składane podczas składania ślubów (= wotów) obejmowały fundowanie ołtarzy, posągów, reliefów, inskrypcji, a nawet całych mitreów ${ }^{19}$. Mitraistyczna jaskinia to miejsce, gdzie składa się „,czyste śluby” (euchesthai hagnos, inskrypcja 2307 w zestawieniu Vermasere$\mathrm{na}^{20}$ ). Inna, łacińska inskrypcja mówi o przyozdobieniu świątyni-jaskini po to, by „wszyscy, trzymając się za ręce, mogli na zawsze radośnie celebrować swe śluby" (ut possint sydexi hilares celebrare vota per aevom) ${ }^{21}$. Na uwagę zasługuje tu słowo syndexi - „trzymający się za prawice”: jest stary gest, wyrażający wierność, stąd mystai są równocześnie syndexioi, przyjaciółmi, towarzyszami drogi. Istotą mitraistycznych obrzędów jest doświadczenie powodzenia oraz akt wiary odnowiony podczas wspólnej uroczystości ${ }^{22}$. Doświadczenie boga jest doświadczeniem osiągalnym we wspólnocie wiernych. To istotny rys mitraistycznego mistycyzmu.

Mitraiści, zdaniem Waltera Burkerta, z czym osobiście nie w pełni się zgadzam, oczekiwali spełnienia swych modlitw w tym życiu, oczekiwali ,powodzenia", które nie było oddalone w czasie, a już tym bardziej nie przechodziło na ,inne życie” po śmierci. Ostatecznie Mitra był deus invictus - 'bogiem niezwyciężonym', a jego wyznawcami w Rzymie byli głównie legioniści, którzy doskonale znali smak doczesnego zwycięstwa. Faktem jest, że brakuje jednoznacznych świadectw, które sugerowałyby, że mitraizm gwarantował swym wyznawcom jakąkolwiek formę transcendentalnego zbawienia ${ }^{23}$, nieśmiertelności, wstąpienia do nieba z jaskini, którą jest świat. $Z$ drugiej jednak strony trudno zaakceptować ten dowód ex absentia i pogodzić się z myślą, że ruch religijny kontynuujący tradycje perskiego zoroastrianizmu i religii perskich mógł nie opierać swych wierzeń na pojęciu nieśmiertelnej duszy i zbawienia. Naprawdę intrygujący jest fakt, że nie mamy żadnych informacji o obrzędach pochówku mitraistów ${ }^{24}$. Znowu jednak jest to dowód ex absentia.

18 Tamże, s. 50-51.

19 Zob. tamże, s. 62 z przyp. 19-20.

20 Według wydania: M.J. Vermaseren, Corpus Inscriptionum et Monumentorum Religionis Mithraicae, t. 2, Hagae 1960.

${ }^{21}$ Inskrypcja 423 (tamże).

22 W. Burkert, Starożytne kulty..., dz. cyt., s. 62.

23 Takie interpretacje L.A. Campbella (Mithraic Iconography and Ideology, Leiden 1968) Burkert uważa za „dzikie” (W. Burkert, Starożytne kulty..., dz. cyt., s. 77, przyp. 85).

${ }^{24}$ Opinię o wspólnym pochówku mitraistów utrzymywał F. Cumont (Die Mysterien des Mithra, Lepizig 1923, s. 160), jednak obecnie contra: W. Burkert, Starożytne kulty..., dz. cyt., s. 77. 


\section{Kult kosmiczny}

W mitraizmie - inaczej niż w pozostałych kultach misteryjnych starożytności - kosmologia pozostaje w samym centrum systemu i rytuału. Jaskinia odbija kosmos, jej sklepienie jest często okryte odwzorowaniem sklepienia nieba ze znakami zodiaku, siedmioma planetami, odpowiedzialnymi za siedem stopni wtajemniczenia. Ofiara z byka - centralny punkt rytuału - zawsze dokonuje się w czasie skoordynowanym z czasem kosmicznym: pomiędzy wschodem Słońca i zachodem Księżyca. Niektóre mitrea miały wejścia, przez które promień słońca mógł wpadać tylko w określone dni roku, oświetlając głowę boga na reliefie.

Mitra jest także ogrodnikiem, który dba o drzewa i dostarcza im wody. Ogon zabijanego byka niejednokrotnie zamienia się na reliefach w kłos zboża, co kieruje uwagę ku kultom wegetacyjnym i analogiom z innymi kultami misteryjnymi $i^{25}$ lub wprost ku synkretycznym zapożyczeniom.

Kosmiczny charakter kultu Mitry wyrażający się w ikonografii oraz czasowym związku obrzędów z cyklami kosmicznymi miał uzasadnienie w metaforycznej strukturze postępu duchowego, o czym pisze Orygenes w Contra Celsum 6, 2226 , gdzie znajdujemy opis drabiny mistycznej:

[...] Celsus opowiada o jakichś misteriach perskich: „Wzmiankę na ten temat, powiada, znajdujemy w naukach perskich, a zwłaszcza w misteriach odprawianych przez Persów ku czci Mitry. Zawierają one symbol dwóch sfer niebieskich - sfery gwiazd stałych i sfery planet, przez które przechodzi dusza. Symbol ten przedstawia się następująco: Jest to drabina zawierająca siedem bram, a na jej szczycie jest umieszczona ósma brama; bramy te są wykonane kolejno z ołowiu, cyny, spiżu, żelaza, brązu, srebra i złota. Uważają, że pierwsza brama należy do Kronosa (Saturna), a ołów symbolizuje powolność tej planety, druga do Afrodyty (Wenus), symbolizowanej przez jasność i miękkość cyny, trzecia - twarda, spiżowa - do Zeusa (Jowisza), czwarta do Hermesa (Merkurego), albowiem żelazo, tak jak Hermes, wytrzymuje wielkie trudy oraz nadaje się do handlu i jest używane do różnorakich prac, piąta - nietrwała i zmienna, bo zbudowana ze stopu - do Aresa (Marsa), szósta, srebrna, do księżyca, a siódma złota, do słońca, albowiem metale te imitują barwę księżyca i słońca". Stara się następnie dociec, dlaczego ten symbolicznie wyobrażony szereg planet został objaśniony za pomocą nazw różnej materii, i wyjaśniając teologię perską usiłuje przystosować do niej argumenty zaczerpnięte ze sztuki muzycznej ${ }^{27}$.

25 W. Burkert, Starożytne kulty..., dz. cyt., s. 151.

${ }^{26}$ Por. obszerny komentarz w: D.K. Malloch, Christ and Taurobolium. Lord Mithras in the Genesis of Christianity, Leven 2006.

27 Tłumaczenie wg wydania: Orygenes, Przeciw Celsusowi, thum.. S. Kalinkowski, Warszawa 1986, s. 301-302. 


\section{Inicjacja}

Bez wątpienia przyszły wyznawca Mitry najpierw musiał odbyć swoisty nowicjat przed przystąpieniem do ceremonii inicjacyjnych i do samej wspólnoty. Musiał poprosić o przyjęcie najwyższego przełożonego wspólnoty. Przekaz Tertuliana nie zostawia wątpliwości: Atquin volentibus initiari moris est, opinor, prius patrem illum sacrorum adire, quae praeparanda sint describere (Apologetyk 8, 728: „Jednak istnieje, jak sądzę, zwyczaj, aby ci, którzy chcą zostać wtajemniczeni, najpierw przyszli do owego ojca świętych obrzędów, aby objaśnił im, jak należy się przygotować" ${ }^{29}$ ); Sine dubio enim initiari volentibus mos est prius ad magistrum sacrorumn vel patrem adire (Ad Nat. 1, 7: „Bez wątpienia istnieje zwyczaj, aby ci, którzy chcą zostać wtajemniczeni, najpierw przyszli do nauczyciela świętych obrzędów lub ojca"30).

Nie wiemy, co było przedmiotem tego przygotowania - pozostaje to owiane tajemnica, tak jak niemal wszystko inne w mitraizmie. W okresie gwałtownego rozwoju tego kultu w Rzymie musiał istnieć problem właściwego przygotowania zgłaszających się licznie adeptów z zachowaniem reguł sztuki i powagi tajemnicy. Autor monograficznego opracowania mitreum zachowanego pod kościołem San Clemente w Rzymie zasugerował nawet, że przed samą świątynią mieściło się coś w rodzaju szkoły dla nowych adeptów ${ }^{31}$.

Jakieś echo tych przygotowań może jednak zawierać papirus z Florencji ${ }^{32}$ :

$\mathrm{Na}$ imię boga, który rozdzielił ziemię od nieba, światło od ciemności, świat od chaosu, życie od śmierci i stworzenie od zniszczenia, bez wahań i ze szczerą wiarą przysięgam zachować tajemnicę misteriów, która zostanie mi przekazana przez pełnego bojaźni przed bogiem ojca Serapiona [...], któremu przypadło to zadanie w udziale i przez moich współtowarzyszy w inicjacji i umiłowanych Braci33.

Świadectwo to, obok odniesień do struktury dopuszczenia do kultu, zawiera też istotne tak dla kultu misteryjnego, jak i dla języka mistyki zestawienia przeciwieństw: światło - ciemność, ziemia - niebo, świat (= kosmos) - chaos, stworzenie - zniszczenie.

Wydaje się, że może to być formuła mitraistycznego sacramentum - przysięgi, która z języka armii rzymskiej przez mitraizm dotarła do chrześcijaństwa.

\footnotetext{
${ }^{28}$ Zob. komentarz W. Burkerta, Starożytne kulty..., dz. cyt., s. 52.

29 Tłumaczenie własne, KB.

30 Tłumaczenie własne, KB.

${ }^{31}$ L. Nolan, The Basilica San Clemente in Rome, Roma 1934, contra M.J. Vermaseren, Mithras. The Secret God, London 1963, s. 130.

${ }^{32}$ M.J. Vermaseren, Mithras. The Secret God, London 1963, s. 130-131.

33 Tłumaczenie własne, KB.
} 
Następne kroki doświadczenia możemy fragmentarycznie poznać z fresków z groty mitraistycznej w Capui: na jednym z nich mystagog ubrany w czerwoną tunikę kładzie ręce na barkach klęczącego przed nim mysty - osoby poddanej wtajemniczeniu, który jest nagi i ma zawiązane oczy. Jeszcze nie wolno mu zobaczyć tajemnicy misteriów. Na innym malowidle do wtajemniczanego, nadal na klęczkach i nadal z zawiązanymi oczami, podchodzi od tyłu mystagog - osoba wtajemniczająca, z mieczem. Na następnym miecz leży obok wtajemniczanego, a mystagog kładzie obie ręce na jego głowie ${ }^{34}$.

Anonimowy tekst z IV wieku, przekazany pod imieniem Amrozjastra (Qaestiones Veteris et Novi Testamenti 114, 11) wyjaśnia funkcję tego miecza podczas inicjacji: alii autem ligatis manibus intestinis pullinis proiiciuntur super foveas aqua plenas, accedente quodam cum gladio et inrupente intestina supra dicta qui se liberatorem appellet (,inni natomiast z rękoma związanymi kurzymi jelitami są wrzucani do dołów pełnych wody, a wówczas zbliża się ktoś z mieczem i przecinając wspomniane jelita nazywa się ich wybawicielem") ${ }^{35}$. Z tym opisem wtajemniczenia koresponduje opinia z leksykonu Suda (s.v. Mí日pov), w której czytamy, że Persowie nazywali Mitrą Słońce, któremu składali liczne ofiary, oraz że nikt nie mógł zostać wtajemniczony

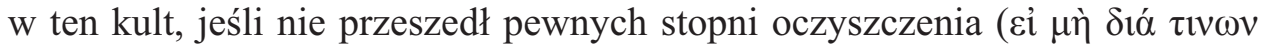

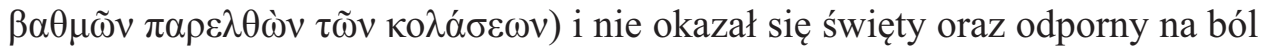

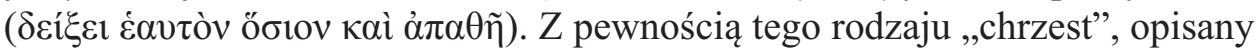
w dziele Ambrozjastra, stanowił lub mógł stanowić doświadczenie graniczne, mistyczne, w terminologii misteryjnej Burkerta: „doświadczenie niezwykłości" ${ }^{\prime 3}$.

Mnich Nonnus z VI lub VII wieku opisał następujące procedury:

Ci, którzy mają być dopuszczeni do mitraistycznych obrzędów, poddawani są wtajemniczeniu poprzez serię prób - najpierw lżejszych, potem bardziej surowych. Na przykład najpierw nakazuje się kandydatom pościć przez 50 dni, a kiedy po tym czasie poddawani są ostrzejszym próbom, są chłostani przez dwa dni, a potem pozostawiani na śniegu lub w zimnej wodzie na dwadzieścia dni. Dopiero po tym są dopuszczani do większych misteriów, jako że dali dowód swej zdolności do wypełniania zalecen ${ }^{37}$.

W VIII wieku biskup Cosmas z Jeruzalem poszedł w opisie jeszcze dalej: według niego w mitraistycznej inicjacji istniało 80 prób, które obejmowały

\footnotetext{
34 Zob. M.J. Vermaseren, Mithras. The Secret God, London 1963, s. 132.

35 Tłumaczenie własne, KB. Por. tamże, s. 133.

36 W. Burkert, Starożytne kulty...., dz. cyt., s. 161-195.

37 Tekst za: M.J. Vermaseren, Mithras. The Secret God, dz. cyt., s. 134, tłumaczenie własne,
} KB. 
„zanurzanie się pod wodę na wiele dni, rzucanie się w ogień, życie w odosobnieniu i powstrzymywanie się od jedzenia"38.

Inicjacyjne tortury i próby ciała związane z przystępowaniem do kolejnych etapów wtajemniczenia przywoływane były głównie przez pisarzy chrześcijańskich (i ich scholaistów). Grzegorz z Nazjanzu mówił o „karze Mitry, słusznie wymierzonej tym, którzy poddali się tego typu inicjacji” (Or. 39, 5), a gdzie indziej $($ Or. 4,70$)$ o ,mistycznych torturach i przypalaniach w sanktuariach Mitry”. Wspomniany Ambrozjaster natomiast donosi o „pięćdziesięciu dniach postu, dwóch dniach chłosty i dwudziestu dniach na śniegu". Niewielu uczonych daje wiarę tym doniesieniom, jednak trudno nie zauważyć, że opisy wyczynów i osiągnięć chrześcijańskich ascetów tego czasu nie odbiegają znacząco od tych informacji.

Tak czy inaczej misteria Mitry z pewnością należały do typowych rytów przejścia, związanych z głębokim przeżyciem niezwykłości pozostawiającym trwały ślad i zmieniającym jakość egzystencji, co stanowi istotną sugestię na temat możliwości występowania u adeptów tych rytów tego, co nazywamy „doświadczeniem mistycznym”39.

Ważny jest też w ikonografii mitraistycznej motyw uczty - najczęściej to Mitra i Helios ucztują razem przy stole nakrytym skórą zabitego w ofierze byka i zjadają jego mięso, a usługują im mystowie na stopniu wtajemniczenia Kruka i Lwa w zwierzęcych maskach. Z kolei Justyn (Apologia 1, 66, 4) donosi o tym, że w misteriach Mitry naśladowano praktyki chrześcijańskie, stawiając na stole kielich z wodą i chleb. Nic więcej jednak o tym nie wiemy.

W mitraizmie brak jest dychotomii duchowni-wierni (obecnej np. w kulcie Izydy), natomiast wyraźnie ryzuje się siedmiostopniowa struktura wspólnoty. Najczęściej mówi się o „siedmiu stopniach wtajemniczenia”, wyliczając kolejno nazwy stopni ${ }^{40}$ : Kruk (Corax), Nowożeniec (Nymphus), Żołnierz (Miles), Lew (Leon), Pers (Persa), Posłaniec Słońca (Heliodromus), Ojciec (Pater, a nawet - na niektórych inskrypcjach ${ }^{41}$ : Pater patrum, czy też - jak

38 Tamże.

39 W tym kontekście należy wspomnieć o dyskusji toczącej się w odniesieniu do związków z mitraizmem krwawego rytuału taurobolium (por. opis Prudencjusza, Peristephanon, 1006-1050). Według dzisiejszego stanu wiedzy obrzęd ten nie ma nic wspólnego z mitraizmem. Jedyna inskrypcja, która to potwierdza (CIL VI, 736), okazała się fałszerstwem. Na wielu inskrypcjach Mitra pojawia się w katalogu bóstw wymienianych w kontekście taurobolium (np. nr 20, 22-24, 26 i 32 w zestawieniu R. Duthoya, The Taurobolium. Its Evolution and Terminology, Leiden 1969), ale żadna z nich nie wskazuje na to, by adepci tego kultu mieli sami odprawiać ten obrzęd.

40 Hieronim (List 107, 2, por. przekład: św. Hieronim, Listy, tłum. J. Czuj, t. 2, Warszawa 1953, s. 402) podaje nieco inne symbole w odmiennej kolejności, przywołując epizod zniszczenia wizerunków mistraistycznych w jaskini kultowej przez niejakiego Grakhusa: Kruk, Gryf, Żołnierz, Lew, Pers, Słońce, Rak, Ojciec.

41 W wydaniu M.J. Vermaserena (CIMRM) nr. 57, 336, 400-403. 
u cytowanego powyżej Tertuliana - Pater sacrorum). Pater był przełożonym wspólnoty odpowiedzialnym za właściwy przebieg inicjacji.

Mitraizm dopuszczał - pilnie selekcjonowanych - niewolników, ale nie dopuszczał kobiet. „Mitra nienawidzi kobiet” mówi Pseudo-Plutarch (De fluv. 23).

Intrygujące, że jakkolwiek uczestnicy misteriów musieli doświadczać wyjątkowego poczucia wspólnoty, to język zachowanych, nielicznych tekstów mitraistycznych i przekazów na ich temat jest bardzo silnie zindywidualizowany. Na przykład w dziele cesarza Juliana, który sam był wtajemniczony w Mitrę i był promotorem tego kultu w Cesarstwie, słyszymy Hermesa, który

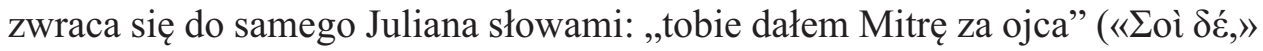

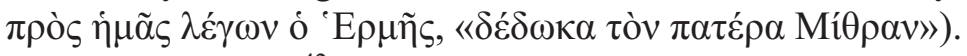

Tertulian pisze ${ }^{42}$, że mitraiście na trzecim stopniu inicjacji nie wolno było nosić wieńca, ponieważ miał on odtąd powtarzać „Mitra jest moim wieńcem”. Wskazuje to na silne uwewnętrznienie doświadczenia oraz na procedury rytualne, których zadaniem było przechodzenie od zewnętrznego symbolu do wewnętrznego przekonania $\mathrm{i}$ istotnej zmiany statusu, opartej na przeżyciu. $\mathrm{Na}$ tym etapie - według Tertuliana (De praescr. haeret. 40) - mystom wypalano rozżarzonym żelazem znak na czole lub oczyszczano ich pochodnią (tak Lukian, Menippus 7$)^{43}$.

Opis inicjacji w czwarty stopień wtajemniczenia ${ }^{44} \mathrm{w}$ mitraizmie podaje Porfiriusz w Grocie $\operatorname{nimf}(15)^{45}$ :

Kiedy w trakcie misteriów Lwa ręce wtajemniczanych polewają miodem zamiast wodą, to wzywa się ich, aby zachowali ręce nieskażone od wszystkiego co niepokojące, raniące czy brudne, a skoro jest to wtajemniczenie w ogień o mocy oczyszczającej, podaje się im stosowny płyn, aby uniknąć wody; ta bowiem nieprzyjazna jest ogniowi. Również za pomocą miodu oczyszcza się język ze wszelkich błędów. $Z$ drugiej strony, kiedy ofiarowali miód Persowi ${ }^{46}$ jako „opiekunowi żniw", to właśnie cechy konserwujące przywołuje się tym symbolem. Oto dlaczego niektórzy sądzą, że miód winien być porównany do nektaru czy ambrozji, o której poeta mówi $(I l .19,38)$, aby ją wlewać do nozdrzy zmarłych w celu ocalenia ich od rozkładu. Miód jest bowiem pokarmem bogów.

42 Cor. 15.

43 Zob. M. Eliade, Historia wierzeń i idei religijnych, tłum. S. Tokarski, Warszawa 1994, t. 2, S. 213.

44 Por. też L.A. Campbell, Mithraic Iconography and Ideology, Leiden 1968, s. 309: z opisem namaszczania mystów miodem na czwartym stopniu wtajemniczenia.

45 Tłumaczenie za wydaniem cytowanym, s. 55.

46 Zdaniem F. Buffière'a, chodzi o w tym wypadku o samego Mitrę (Mythes d'Homère et la pensée grecque, Paris 1956, s. 605, przyp. 17). 
Na szczególną uwagę zasługuje inskrypcja szczęśliwie zachowana w mitreum Santa Prisca: Viros servasti eternali sanguine fuso: „Mężów ocaliłeś przez rozlew wiecznej krwi" ${ }^{4}$.

Widoczna jest tutaj koncepcja zbawienia (servasti) przez śmierć (sanguine fuso), z odniesieniem do boga zabijającego byka. Czyn spełniony przez boga jest w mitraizmie podstawowym wizerunkiem zbawienia jako takiego, zawierającego w sobie nadzieję poszczególnych osób skupionych wokół tego kultu, nadzieje dotyczące zarówno teraźniejszości, jak i przyszłości. Idea ta jest - jak podsumowuje Burkert - tyleż prymitywna, co fundamentalna i trudno ją zastąpić jakąkolwiek uproszczoną spirytualizacją ${ }^{48}$.

Inskrypcji, rzeźb i malowideł mitraistycznych Maarten Jozef Vermaseren zebrał ponad 3000 (w pierwszym tomie -1002 , w drugim $-2353^{49}$ ). Ogromna większość z nich, właściwie niemal wszystkie, to klasyczne dedykacje - wota, świadectwa wydatkowania pieniędzy na rzeźby, kult i inicjacje, spisywane w intencjach swoich własnych, swoich bliskich lub władców. Nic to bogactwo inskrypcji nie mówi nam o samym kulcie, o inicjacji ani tym bardziej o doświadczeniu. Chociaż więc można traktować te świadectwa jako dane ,z pierwszej ręki”, to de facto i tak pozostajemy z pustymi rękoma.

$\mathrm{Z}$ jednej strony ubóstwo źródeł pisanych nie pozwala na jakikolwiek wgląd w naturę mistycznego doświadczenia mitraistycznego, z drugiej trudno przyjąć, aby kult otoczony tajemnicą, skoncentrowany na indywidualnej wielostopniowej inicjacji, dokonującej się w kontekście symboliki kosmicznej, wegetacyjnej, oparty na surowych wymaganiach względem trybu życia i warunków wstępnych, niejednokrotnie połączony z elementami daleko posuniętej ascezy ciała, pozostawał jedynie pustym obrzędem. Wyraźna w epigrafice i ikonografii idea zbawienia przez krew, znaczenie wspólnoty jako miejsca osobistej drogi o charakterze duchowym, wzmianki o postach i wyrzeczeniach, wreszcie - radykalna niewypowiadalność raczej skłaniają do wzięcia na poważnie duchowych doświadczeń mystów niż do ich deprecjonowania.

Proklos, nowoplatoński filozof z V wieku n.e., na temat misteriów starożytnych napisał: „Sprawiają one, że dusze włączają się w te obrzędy w sposób dla nas niezrozumiały i boski, tak że jedni z wtajemniczanych wpadają w przerażenie, przepełnieni szacunkiem dla bogów, inni zaś przywierają do świętych

$47 \mathrm{Nr} 485$ w klasyfikacji M.J. Vermaserena (Corpus Inscriptionum et Monumentorum Religionis Mithraicae, t. 1, Hagae 1956, s. 200), tłumaczenie własne, KB; zob. też komentarz W. Burkerta, Starożytne kulty..., dz. cyt., s. 192.

48 W. Burkert, Starożytne kulty..., s. 192.

49 M.J. Vermaseren, Corpus Inscriptionum et Monumentorum Religionis Mithraicae, t. 1 i 2 , dz. cyt. 
symboli i tracą swoją własną tożsamość, cali łączą się z bogami i dostępują wypełnienia bogiem" (In Remp. II, 108, 17-30) $)^{50}$.

Alchemik i gnostyk Zosimos, z Panopolis w Egipcie, w książce $O$ tym, co nieugaszone (Peri tou asbestou) gdzieś w IV w. n.e. napisał ${ }^{51}$ :

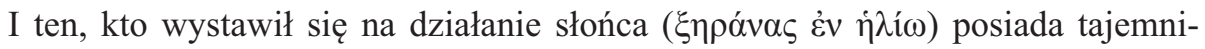

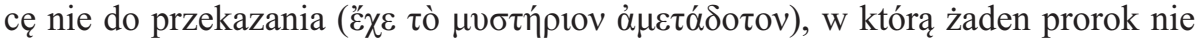

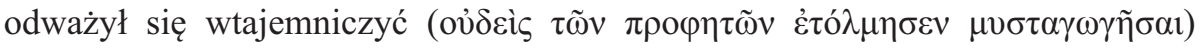

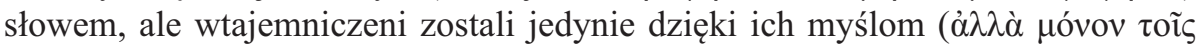

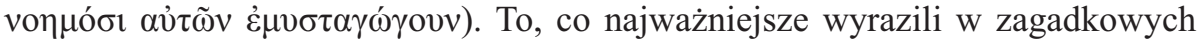

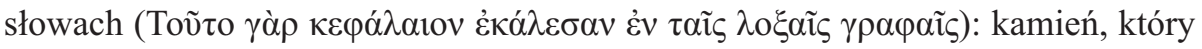

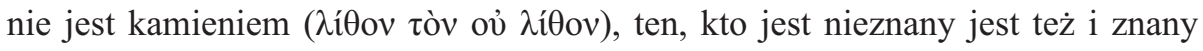

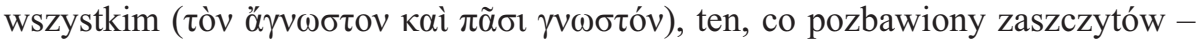

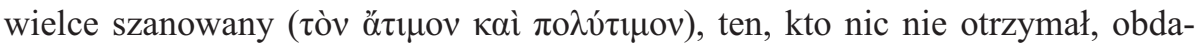

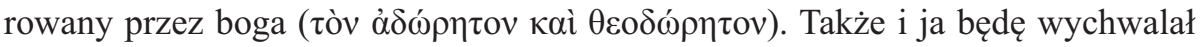
tego, który nic nie otrzymał i jest obdarowany przez boga, tego jedynego, który jest silniejszy od materii (

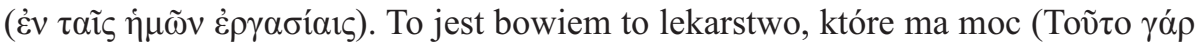

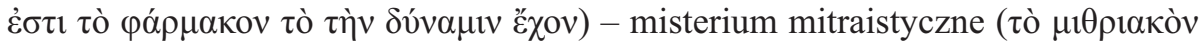

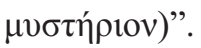

To późne źródło z wyjątkową intensywnością skupia w sobie cechy obydwu języków: techniczny język kultu misteryjnego oraz metaforyczny i paradoksalny język opisu doświadczenia mistycznego. Stanowi, jak sądzę, efekt i skutek kilkuwiekowej kumulacji doświadczeń duchowych wyznawców kultu Mitry i pozwala na wniknięcie jeśli nie $\mathrm{w}$ istotę, to przynajmniej widzialne i wtórne efekty mistycznego doświadczenia inicjowanych, w swoistą ramę modalną mistyki mitraistycznej.

Może się wydawać, że powyższe zestawienie cytatów stoi w sprzeczności z opiniami uczonych przywołanymi w uwagach wstępnych na temat ubóstwa źródeł mitraistycznych. Należy jednak raz jeszcze podkreślić, że wszystkie wspomniane tutaj świadectwa stanowią jedynie zewnętrzny opis i poza danymi archeologicznymi nie mamy dostępu do żadnych informacji bezpośrednich na temat doświadczenia religijnego czy mistycznego w mitraizmie. Wydaje się jednak równocześnie, że źródła sekondarne i rekonstrukcje archeologiczne pozwalają wysuwać wnioski, które zmuszają do uznania faktu, że mitraizm stwarzał warunki dla głębokich doświadczeń o charakterze duchowym.

50 Tłumaczenie własne, KB.

51 M. Berthelot, C.E. Ruelle, Collection des anciens alchemistes grecs, t. 2, Paris 1888, s. 113-114 , tłumaczenie własne KB. 


\title{
MYSTIC EXPERIENCE IN MITHRAISM
}

\begin{abstract}
Summary
The paper attempts to describe and interpret mystical experience in the structure of ancient cult of Mithra in his Roman appearance, following the reconstruction of the myth and cultic customs, based on archeological and iconographical evidence as well as on external sources, mainly coming from the works of Christian writers.
\end{abstract}

Keywords: ancient mystery cults; Mithraism; Mithra; Greek and Roman religions; mystic experience

Slowa kluczowe: starożytne kulty misteryjne; mitraizm; Mitra; religia grecka i rzymska

\section{BIBLIOGRAFIA}

Berthelot M., Ruelle C.E., Collection des anciens alchemistes grecs, t. 2, Paris 1888.

Bielawski K., Arrheton - niewypowiadalne w greckich kultach misteryjnych, „Filozofia Chrześcijańska" 13 (2016), s. 37-52.

Bielawski M., Tytul teologa. Casus Jana Ewangelisty, Grzegorza z Nazjanzu i Symeona Nowego Teologa, w: M. Bielawski, Mikroteologie, Kraków 2008, s. 11-28.

Bivar A.D.H., The Personalities of Mithra in Archeology and Literature, New York 1998.

Buffière F., Mythes d'Homère et la pensée grecque, Paris 1956.

Burkert W., Starożytne kulty misteryjne, tłum. K. Bielawski, Bydgoszcz 2001.

Campbell L.A., Mithraic Iconography and Ideology, Leiden 1968.

Cumont F., The Mysteries of Mithra, transl. Th.J. McCormack, Chicago 1903 (wydanie późniejsze poprawione: F. Cumont, Die Mysterien des Mithra, Lepizig 1923).

Duthoy R., The Taurobolium. Its Evolution and Terminology, Leiden 1969.

Eliade M., Historia wierzeń i idei religijnych, tłum. S. Tokarski, t. 2, Warszawa 1994.

Guthrie K.S., The Mithraic Mysteries Resored and Modernized. A Drama of Interior Initiation. Employing all the available Data and Survivals of the Historic Persio-Roman Mithraics, Embodying Versions of Zoroastrian Scriptures. Combining the Religions of All Races and Times, With the best Modern Spiritual Thought, With Experiments for Every Day of the Year, Teocalli 1925.

Malloch D.K., Christ and Taurobolium. Lord Mithras in the Genesis of Christianity, Leven 2006.

Nolan L., The Basilica San Clemente in Rome, Roma 1934.

Rénan E., Marc Aurèle et la fin du monde antique, Paris 1882.

Vermaseren M.J., Corpus Inscriptionum et Monumentorum Religionis Mithraicae (=CIMRM), t. 1, Hagae 1956.

Vermaseren M.J., Corpus Inscriptionum et Monumentorum Religionis Mithraicae (=CIMRM), t. 2, Hagae 1960.

Vermaseren M.J., Mithras. The Secret God, London 1963.

KrZYSZTOF BIELAwSKI (1969) - adiunkt w Instytucie Filologii Klasycznej UJ, absolwent wydziału teologicznego PAT, wykładowca krakowskiej PWST, filo- 
$\log$, patrolog, tłumacz. Zajmuje się badaniami nad leksykografią grecką, religią antyczną i rytuałami ofiarnymi, antycznymi fragmentami muzycznymi, kultami misteryjnymi oraz związkami tragedii z teologią. Wydał m.in.: Terminy rytualnokultowe $w$ tragedii greckiej epoki klasycznej (2004), Teksty poetyckie greckich fragmentów muzycznych (2012), Ani święty, ani spokój. Sylwy religijne - antyk, chrześcijaństwo (2013). Mieszka w Krakowie. 